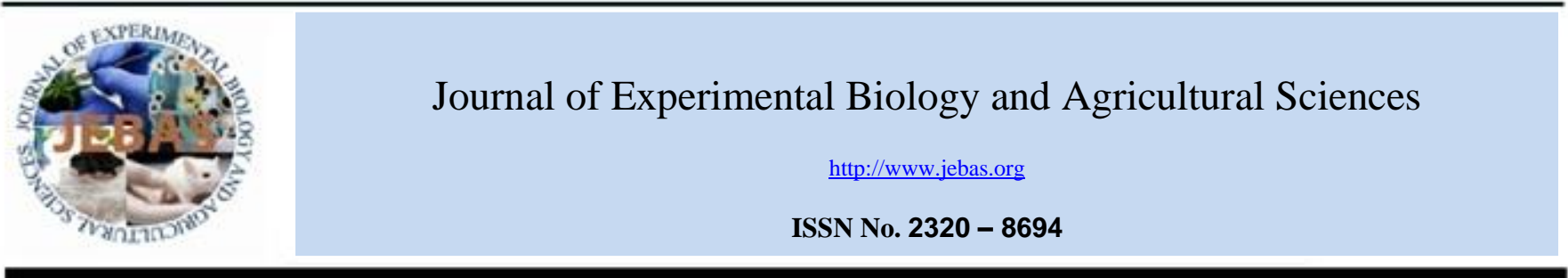

\title{
BRAIN COMPUTER INTERFACE (BCI) ON ATTENTION: A SCOPING REVIEW
}

\author{
Anita Prem*, K Mohanraj, A Rajan Samuel
}

Vinayaka Mission's College of Physiotherapy, Vinayaka Mission's Research Foundation (Deemed to be University), Salem-636308, Tamilnadu, India

Received - July 18, 2020; Revision - September 17, 2020; Accepted - October 29, 2020

Available Online - March 25, 2021

DOI: http://dx.doi.org/10.18006/2021.9(Spl-1-GCSGD_2020).S10.S22

\section{KEYWORDS \\ Attention \\ Brain Computer Interface (BCI) \\ Neurofeedback Training \\ Cognition}

Electroencephalogram (EEG)

\begin{abstract}
Technological innovations are now an integral part of healthcare. Brain-computer interface (BCI) is a novel technological intervention system that is useful in restoring function to people disabled by neurological disorders such as attention deficit hyperactivity disorder (ADHD), amyotrophic lateral sclerosis (ALS), cerebral palsy, stroke, or spinal cord injury. This paper surveys the literature concerning the effectiveness of $\mathrm{BCI}$ on attention in subjects under various conditions. The findings of this scoping review are that studies have been made on ADHD, ALS, ASD subjects, and subjects recovering from brain and spinal cord injuries. BCI based neurofeedback training is seen to be effective in improving attention in these subjects. Some studies have also been made on healthy subjects.BCI based neurofeedback training promises neurocognitive improvement and EEG changes in the elderly. Different cognitive assessments have been tried on healthy adults. From this review, it is evident that hardly any research has been done on using BCI for enhancing attention in post-stroke subjects. So there arises the necessity for making a study on the effects of BCI based attention training in post-stroke subjects, as attention is the key for learning motor skills that get impaired following a stroke. Currently, many researches are underway to determine the effects of a BCI based training program for the enhancement of attention in post-stroke subjects.
\end{abstract}

* Corresponding author

E-mail: anitapremphysio@gmail.com (Anita Prem)

Peer review under responsibility of Journal of Experimental Biology and Agricultural Sciences.

Production and Hosting by Horizon Publisher India [HPI] (http://www.horizonpublisherindia.in/).

All rights reserved.
All the articles published by Journal of Experimental Biology and Agricultural Sciencesare licensed under a Creative Commons Attribution-NonCommercial 4.0 International License Based on a work at www.jebas.org.

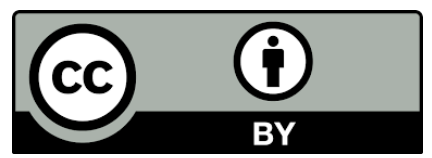




\section{Introduction}

In the world today, technology is inevitable in every aspect of life Healthcare is an important industry in which technology plays a crucial role. Technological innovations are indispensable for treating disorders and sustaining health. This paper surveys studies on how brain-computer interface (BCI) has made inroads into cognitive rehabilitation, specifically in improving attention. Attention is a cognitive function that selects and acts on a particular stimulus among many other stimuli. It processes sensory stimuli and mental tasks like memory and thoughts (Esghaei \& Daliri, 2014; Treder et al., 2014). William James, one of the most influential psychologists asserts that it is the taking possession of one out of several simultaneously possible objects or trains of thought, by the mind in clear and vivid form. He points out that attention is the focalization and concentration of consciousness (James, 1891).

Sustained attention is the capacity to concentrate on a particular task for a long period without being distracted. Concentrating on reading or writing is an example. Improvement in attentional processing and reduction of reaction time to the target stimuli are the result of the training of sustained attention such as meditation (Lutz et al., 2009). Alternative attention indicates flexibility in mental activity. An example is reading instructions (learning task) and fixing an instrument according to the instructions (execution task). In other words, it is the alternating of concentration between two different cognitive tasks. An increase in mental fatigue is associated with impairment in alternative attention (Kawatani et al., 2011; Mizuno et al., 2011). The ability to select a particular stimulus among various stimuli is called selective attention. Recognizing a particular voice in a noisy surrounding is an example of selective attention. While selecting a particular signal among different signals, the reaction time and place of the target stimulus may be better predicted, and this improves the judgment of the task (Spence \& Driver, 1997; Spence et al., 2001). Divided attention is the performance of two or more tasks simultaneously, so that attention is divided among these tasks. Attentional and processing resources are assigned differently between dual tasks in divided attention (Shapiro et al., 2006).

In the field of neurological rehabilitation, evaluating and managing cognitive function is an ingenious and hardly explored area. Attention Process Training (APT) method has been studied and found to be a valuable intervention method for patients with attention-deficit. However, this method has certain limitations like limited generalizability to wider samples, chance findings, and influenced outcomes.

The use of Brain-Computer Interface (BCI) to enhance motor and cognitive recovery is a novel approach. The use of BCI has certain advantages of brain activation monitoring, in particular, the monitoring of the global level of attention concerning a task, and the level of interhemispheric balance (Carelli et al., 2017). The need arises for the study on the use of BCIs for cognitive training to improve the patients' clinical conditions. Further, the treatment may be made more efficacious by providing real-time feedback, which enhances neural plasticity. The use of BCIs to improve attention has not been much explored. Some reviews discuss the current status of BCI interventions in varied uses. Studies in this area include BCIs using auditory, tactile, and motor imagery-based designs (Naci et al., 2012; Muller-Putz et al., 2013). BCI is a noninvasive biofeedback system that can be used in training for cognition, emotion function, and motor learning (Daly \& Huggins, 2015). In BCI intervention, functional magnetic resonance imaging (fMRI), Functional near-infrared spectroscopy (fNIRS) and electroencephalography (EEG) can be used to restore some communicative ability in these patients (Luaute et al., 2015).

Among the non-invasive methods available for recording brain activity, EEG and fNIRS seem to be the best potential candidates for usage in post-brain injury rehabilitation (Dokkum et al., 2015). $\mathrm{BCI}$ in conjunction with a $3 \mathrm{D}$ virtual environment is found to be effective in the treatment of post-stroke patients (Denis et al., 2007). The combination of BCI-MI plus orthosis with physical training may help to improve upper limb motor control post-stroke (Ramos-Murguialday et al., 2013).

Improving attention in patients with disorders of attention using BCI is a relatively new approach. BCIs use mathematical algorithms to decipher nerve impulses. Patients can monitor the activity of their brain at the time of occurrence and regulate it by themselves. This is called "neuro bio-feedback therapy". BCIs commonly utilize EEG recordings, magnetoencephalography (MEG), near infra-red spectroscopy (NIRS), functional magnetic resonance imaging (fMRI), electrocorticography $(\mathrm{ECoG})$, and multi-electrode intracranial implants (Mehdi et al., 2016). Meta-analyses and randomized controlled trials conducted on ADHD have shown that three standard neurofeedback training protocols are specific - theta/beta (TBR), sensorimotor rhythm (SMR), and slow cortical potential (SCP) (Enriquez-Geppert et al., 2019). A meta-analysis with 10 randomized controlled trials shows that the effects of neurofeedback in ADHD children increase in time, while the medication effects diminish with time, thus suggesting the longterm efficacy of neurofeedback (Van Doren et al., 2018). Some studies have been done on real time (RT) brainwave based neurofeedback for improving attention in older adults combating cognitive decline and brain aging (Jiang et al., 2017).

We here present a scoping review about BCI applications dealing with attention issues, in both healthy individuals and subjects with various cognitive impairments such as attention deficit hyperactivity disorder (ADHD), amyotrophic lateral sclerosis (ALS), autistic spectrum disorder (ASD), post stroke disabilities, cognitive deficit following brain and spinal cord injuries, and dementia. 
Table 1 BCI on Attention Deficit Hyperactivity Disorder (ADHD)

\begin{tabular}{|c|c|c|c|c|c|}
\hline Study & $\begin{array}{l}\text { Paradigm/ } \\
\text { Signals }\end{array}$ & Sample \& Method & $\begin{array}{c}\text { Tested } \\
\text { Variables }\end{array}$ & Outcome Measure & Limitations \\
\hline $\begin{array}{l}\text { Lim et al. } \\
\text { (2012) }\end{array}$ & $\begin{array}{l}\text { Frontal EEG } \\
\text { Fp1 \& Fp2 }\end{array}$ & $\begin{array}{l}20 \text { ADHD unmedicated } \\
\text { children }(16 \mathrm{M} \& 74 \mathrm{~F}) 6- \\
\text { 12yrs. } \\
\text { 3D graphic game } \\
\text { (CogoLand) }\end{array}$ & $\begin{array}{c}\text { Inattention } \\
\text { symptoms } \\
\text { (accuracy\& } \\
\text { execution time), } \\
\text { hyperactive } \\
\text { impulsive } \\
\text { symptoms. } \\
\end{array}$ & $\begin{array}{l}\text { ADHD-Rating } \\
\text { Scale based on the } \\
\text { DSM-IV criteria }\end{array}$ & $\begin{array}{l}\text { Uncontrolled open- } \\
\text { label trial could } \\
\text { have resulted in an } \\
\text { exaggerated } \\
\text { treatment effect. }\end{array}$ \\
\hline $\begin{array}{l}\text { Munoz et } \\
\text { al. (2015) }\end{array}$ & $\begin{array}{c}\text { Neuromodulation } \\
\text { of Beta \& Theta } \\
\text { waves }\end{array}$ & $\begin{array}{c}\text { Children with ADHD 8- } \\
13 \text { yrs. without } \\
\text { depression/ } \\
\text { comorbidity. } \\
\text { Mindwave neuro- } \\
\text { headset. Videogames }\end{array}$ & $\begin{array}{l}\text { Waiting ability, } \\
\text { Planning ability, } \\
\text { Ability to follow } \\
\text { instructions \& } \\
\text { to achieve } \\
\text { objectives. }\end{array}$ & $\begin{array}{c}\text { E-sense attention } \\
\text { meter } \\
\text { (Mindwave), } \\
\text { Theta/Beta ratio. }\end{array}$ & \\
\hline $\begin{array}{l}\text { Qian et al. } \\
\text { (2018) }\end{array}$ & $\begin{array}{l}\text { Frontal EEG Fp1 } \\
\& \text { Fp2 }\end{array}$ & $\begin{array}{l}51 \text { boys (ADHD) -- } \\
\text { Intervention group (33) } \\
\text { \& Control group (18) } \\
3 \text { BCI based training } \\
\text { sessions per week for } 8 \\
\text { weeks, } \\
\text { 3D graphic game } \\
\text { (CogoLand) }\end{array}$ & $\begin{array}{l}\text { Inattention \& } \\
\text { Internalizing } \\
\text { symptoms }\end{array}$ & $\begin{array}{c}\text { Resting-state } \\
\text { functional } \\
\text { magnetic } \\
\text { resonance } \\
\text { imaging method, } \\
\text { DHD-RS clinician } \\
\text { inattention scores, } \\
\text { Child behaviour } \\
\text { checklist }\end{array}$ & $\begin{array}{l}\text { Physiological noise } \\
\text { in the functional } \\
\text { magnetic resonance } \\
\text { imaging } \\
\text { (fMRI) pre- } \\
\text { processing } \\
\text { techniques. } \\
\text { Clinical hetero } \\
\text { geneity of ADHD } \\
\text { not taken into } \\
\text { account. }\end{array}$ \\
\hline $\begin{array}{l}\text { Lim et al. } \\
\text { (2019) }\end{array}$ & $\begin{array}{l}\text { EEG waves } \\
\text { Fp1 \& Fp2 }\end{array}$ & $\begin{array}{c}172 \text { children with } \\
\text { combined subtypes of } \\
\text { ADHD aged } \\
6 \text { to12. } \\
\text { BCI training }-3 \text { sessions } \\
\text { / } 8 \text { weeks. } \\
3 \text { follow-up training } \\
\text { sessions / month - } 12 \\
\text { weeks }\end{array}$ & $\begin{array}{l}\text { Clinician-rated } \\
\text { inattention } \\
\text { symptoms, } \\
\text { Short term efficacy, } \\
\text { maintenance effect } \\
\text { and long-term } \\
\text { effect. }\end{array}$ & $\begin{array}{l}\text { ADHD rating } \\
\text { scale (ADHD- } \\
\text { RS), Child } \\
\text { behaviour } \\
\text { checklist (CBCL) } \\
\text { \&Paediatrics } \\
\text { adverse events } \\
\text { rating scale } \\
\text { (PAERS). }\end{array}$ & $\begin{array}{l}\text { The trial results } \\
\text { cannot be } \\
\text { generalized as } 90 \% \\
\text { of the participants } \\
\text { were males. } \\
\text { Possibility of } \\
\text { response bias }\end{array}$ \\
\hline
\end{tabular}

\section{Materials and Methods}

From February to April 2020, we searched the databases PubMed, Web of Science, and Scopus, using the search phrase "brain computer interface in attention". Since attention disorders come under a cognitive deficit, the terms "BCI or brain computer interface on cognition" were also included in the search. As BCI is a method of neurofeedback training, we later included the phrase "Neurofeedback training on attention using BCI". Most of the studies selected for this review are on training attention using BCI, but a few studies on evaluating attention while performing another motor task have also been included. A total number of 618 studies have been found with PubMed, 2282 studies with Web of Science, and 2313 studies with Scopus, using the above terms.
We filtered the search down to 23 researches relevant to this review, which are included in Tables 1-5. The study samples included in this review cover both subjects affected by cognitive impairments and healthy subjects without any such cognitive deficit. Only studies in English have been considered in this review.

\section{Results and Discussion}

\subsection{BCI in Attention Deficit Hyperactivity Disorder (ADHD)}

Brain-computer interface has been experimented with as a neurofeedback therapy for ADHD. A BCI-based 3D game for attention training and rehabilitation was devised specifically for 
ADHD subjects (Jiang et al., 2011). In this approach, BCI technology is used to translate the user's mental state of attention into game control. When the user controls a virtual hand's movement in a $3 \mathrm{D}$ animation technique, the $\mathrm{BCI}$ engine measures his/her attention level. This system is found to be more economical, engaging, and easier to use than the robotic based system. It can also be used in the treatment of patients suffering from neurological disorders caused by trauma.

A group of researchers evaluated a BCI based attention training program for treating ADHD, which included dry sensors and blue tooth technology in place of EEG leads with a game CogoLand (Lim et al., 2012). The training was given for eight weeks in 24 sessions. A follow-up of booster training sessions was given for three months. After the intervention, the parents rated the significant improvement in inattentive and hyperactive-impulsive symptoms in the ADHD subjects. Children, who have inattentive and combined subtypes, are found to benefit from the treatment more generally than the hyperactive-impulsive subtypes. Studies on neuro-imaging have shown that the brain functions responsible for selective attention and response inhibition in children with ADHD may be functionally normalized by neurofeedback therapy (Beauregard \& Levesque, 2006). The limitation of this study is an uncontrolled open-label trial, the parents who completed the behavioral rating scale were not blinded and the children's school teachers presented a high non-response rate.

A videogame was developed using a BCI to keep track of neurophysiologic signals (Munoz et al., 2015). The name of the game was "The Harvest Challenge" and the setting was a coffee plantation. The games using an avatar were meant to boister up the waiting and planning abilities and the abilities to follow instructions and to achieve objectives. When these abilities are improved, inattention impulsiveness can be brought under control. The modulation of Beta and Theta waves, with the help of an electrode placed in the central part of the frontal lobe of the brain, was used for training sustained attention in children with ADHD.

An experiment with a BCI based intervention was conducted to renormalize brain functional network topology in children with ADHD (Qian et al., 2018). The researchers used the resting-state fMRI method to examine the changes in the topology of brain functional networks. After training, it was found that the inattention symptoms of the intervention group had greatly reduced, compared to the non-intervention group. The BCI-based intervention can help to bring back to normalcy the topology of brain functional network associated with improvement in behaviour, and also expedite brain maturation in children with ADHD (Qian et al., 2018). The limitation of this study is that the ADHD subtypes, which may have a unique response of brain networks, are which not taken into consideration, due to the limited sample size.
A randomized controlled trial (RCT) was carried out to find out whether inattentive symptoms in children with ADHD could be improved by administering a BCI based attention training programme for 8 weeks. A lower-intensity training was also given in the subsequent 12 weeks (Lim et al., 2019). The inattentive symptoms of ADHD showed significant improvement after the programme, when compared to the untreated wait-listed control group. Earlier studies across different populations have shown that ADHD subjects experience significant anxiety and mood symptoms which can increase their impairment (Jensen et al., 2001; Xia et al., 2015). This BCI-based attention training programme alleviated these internalizing symptoms in the subjects under study. This is important because, if ADHD children develop anxiety symptoms during treatment, there is likely to be a poorer outcome (Sciberras et al., 2014). As almost 90\% of the participants in this study were males, the results of the trial cannot be generalized. Also, there is a possibility of response bias among the parents who participated.

\subsection{BCI in Amyotrophic Lateral Sclerosis (ALS)}

Studies on BCIs controlled by people with ALS have been conducted (Sciberras et al., 2014; Sellers et al., 2006; Hoffmann et al., 2008). A single-case report has demonstrated the possibility of long-term independent home use for severely disabled people with ALS (Sellers et al., 2010).

Home based BCI use has made a significant contribution to the quality of life and productivity of the user. Some researchers investigated how attention and memory processes support the control of a P300-based BCI in people with ALS (Riccio et al., 2013). The study was made on a sample of 8 subjects with ALS. They had to perform two behavioural tasks: a rapid serial visual presentation (RSVP) task, and a change detection task. A P300based BCI spelling task was also given to the participants. They concluded that the potential to keep the attentional filter active while choosing a target controls the $\mathrm{BCI}$ performance.

In a further study, the capacity of a sample of ALS patients to control a P300-based BCI device for attention processing, concerning healthy subjects was investigated (Riccio et al., 2018). 13 ALS subjects and 13 healthy volunteers in the same age group and with the same education were given a P300-speller BCI task and a rapid serial visual presentation (RSVP) task. The RSVP task was meant to assess the temporal attentional filtering capacity and the ability to improve the attentive filter in the periodic regularity of selective attention (Riccio et al., 2018). ALS patients showed changes in both the ability and the timing in the execution of the P300-speller task. The finding was that the lower capacity for ALS to control a P300-speller was related to the ability to filter a target stimulus temporally from among a crowd of stimuli. A central issue of BCI research is to develop assistive technology (AT) 
Table 2 BCI on Amyotrophic Lateral Sclerosis (ALS) \& Autistic Spectrum Disorder (ASD)

\begin{tabular}{|c|c|c|c|c|c|}
\hline Study & $\begin{array}{l}\text { Paradigm/ } \\
\text { Signals }\end{array}$ & Sample \& Method & Tested Variables & Outcome Measure & Limitations \\
\hline $\begin{array}{l}\text { Riccio et al. } \\
\text { (2013) }\end{array}$ & $\begin{array}{c}\text { Scalp EEG } \\
\text { signals Fz, Cz, } \\
\text { Pz, Oz, P3, P4, } \\
\text { PO7 \& PO8 }\end{array}$ & $\begin{array}{c}9 \text { volunteers } \\
\text { (6 M \&3F) mean age } \\
59.7 \text { with ALS } \\
\text { diagnosis. } \\
\text { Task- controlling a } 6 \text { by } \\
6 \text { P300 speller. }\end{array}$ & $\begin{array}{l}\text { Temporal attention } \\
\text { capabilities, } \\
\text { memory capacity \& } \\
\text { spatial filtering } \\
\text { capacity. }\end{array}$ & $\begin{array}{l}\text { P300 Speller } \\
\text { Interface, Rapid } \\
\text { Serial Visual } \\
\text { Presentation } \\
\text { (RSVP) task \& } \\
\text { Change Detection } \\
\text { (CD) task. }\end{array}$ & \\
\hline $\begin{array}{c}\text { Amaral et al. } \\
(2018)\end{array}$ & $\begin{array}{c}\text { P } 300 \text { \& alpha } \\
\text { power }\end{array}$ & $\begin{array}{l}15 \text { participants aged } \\
\text { between } 16 \& 38 \text { yrs. } \\
\text { with ASD. } \\
\text { VR interface- } 7 \text { sessions } \\
\text { in } 4 \text { months. Follow up } \\
\text { after } 6 \text { months - joint } \\
\text { attention task }\end{array}$ & $\begin{array}{l}\text { Identification of } \\
\text { social attention } \\
\text { items, sensory } \\
\text { /cognitive } \\
\text { awareness \& } \\
\text { adapted behaviour } \\
\text { composite in DLS. }\end{array}$ & $\begin{array}{c}\text { Eye-tracking, } \\
\text { Autism Treatment } \\
\text { Evaluation } \\
\text { Checklist (ATEC) } \\
\text { \& Vineland } \\
\text { Adaptive } \\
\text { Behaviour Scale } \\
\text { (VABS). }\end{array}$ & $\begin{array}{l}\text { Clinical validation } \\
\text { of the primary } \\
\text { outcome measure } \\
\text { (eye-tracking) is not } \\
\text { done. } \\
\text { Realistic nature of } \\
\text { the VR environment } \\
\text { may be improved. }\end{array}$ \\
\hline $\begin{array}{l}\text { Riccio et al. } \\
\text { (2018) }\end{array}$ & $\begin{array}{c}\text { P300 based } \\
\text { electro } \\
\text { des } \\
\text { Fz, Cz, Pz, Oz, } \\
\text { P3, P4, PO7 \& } \\
\text { PO8 }\end{array}$ & $\begin{array}{l}13 \text { ALS participants (8 } \\
\text { M \& } 5 \text { F) aged 62-75 \& } \\
13 \text { participants ( } 9 \mathrm{M} \mathrm{\&} \\
4 \text { F) with no disorders } \\
\text { (control gp.). } \\
2 \text { sessions } \\
\text { BCI session P300 } \\
\text { speller BCI task } \\
\text { Psychological session - } \\
\text { RSVP task }\end{array}$ & $\begin{array}{l}\text { Selective attention, } \\
\text { working memory \& } \\
\text { executive functions. }\end{array}$ & $\begin{array}{l}\text { The computerized } \\
\text { test for attentional } \\
\text { performance } \\
\text { (TAP) \& } \\
\text { Wisconsin Card } \\
\text { Sorting Test } \\
\text { (WCST). }\end{array}$ & $\begin{array}{l}\text { Can't be generalized } \\
\text { as locked in state } \\
\text { (LIS) not included. }\end{array}$ \\
\hline
\end{tabular}

devices to restore communication in people with severe motor disabilities (Millán et al., 2010). Attention is a complex territory of cognitive functions (Posner, 1975).There are many ways to measure the attention substrates. Different contexts and different approaches show different results and so a direct comparison is not possible.

\subsection{BCI in Autistic Spectrum Disorder (ASD)}

A clinical trial was made using a BCI to improve social attention in ASD (Amaral et al., 2018). The authors experimented with an EEG based BCI to train social cognition skills in ASD patients. Fifteen 22-23-year-old ASD subjects underwent the trial and they were made to participate in a BCI training schedule using a virtual reality (VR) interface. The training was spread over seven sessions in 4 months. The task consisted of identifying objects through the gaze direction of an avatar. The EEG P300 component recorded the attentional responses. A follow-up assessment was made after six months. The subjects showed improvement in adapted behaviour composite and their depression level also decreased. The limitation of the study is that the primary outcome measure has not been validated clinically. For training social attention skills more efficiently, the VR environment may be improved.

\subsection{BCI on Attention in Stroke}

Journal of Experimental Biology and Agricultural Sciences http://www.jebas.org
One of the major causes of dysfunction in adults is said to be a stroke, and a large number of training-oriented rehabilitation techniques have been developed. But they have often failed to work successfully on patients with severe deficits.BCI holds promise for such patients by recording and decoding brain activity while trying to perform motor and cognitive tasks. It can instigate movement, provide feedback on motor imagery, and monitor the comprehensive level of attention in performing tasks and the level of inter-hemispheric balance. An important issue in motor learning is the amount of mental workload, or how hard the brain is working to meet task demands (Ayaz, 2012).

Near infra-red spectroscopy (NIRS) measured activity over the prefrontal cortex could discriminate between low and moderate levels of workload (Mandrick et al., 2013a; Mandrick et al., 2013b), with a plateau effect towards higher levels of workload. Further, whatever the task duration may be, NIRS is found to be highly responsive to a decrease in attention. From the results, it may be inferred that it is possible to monitor changes in attention during BCI training. Researchers investigated the use of BCI along with exoskeleton technology to bring about multimodal stimulation in the rehabilitation of stroke subjects (Kotov et al., 2019). The experimental group was given complex multimodal stimulation involving several techniques along with BCI training, while only BCI training was administered to the control group. Subjects in the main group showed better improvement in memory, attention, and other skills, than the subjects in the control group. 
Table 3 BCI on Stroke, Brain \& Spinal Cord Injuries

\begin{tabular}{|c|c|c|c|c|c|}
\hline Study & $\begin{array}{l}\text { Paradigm/ } \\
\text { Signals }\end{array}$ & Sample \& Method & $\begin{array}{c}\text { Tested } \\
\text { Variables }\end{array}$ & Outcome Measure & Limitations \\
\hline $\begin{array}{l}\text { Salisbury et } \\
\text { al. (2016) }\end{array}$ & $\begin{array}{c}14 \text { channel EEG } \\
\text { recording } \\
(\mathrm{AF} 3, \mathrm{~F} 7, \mathrm{~F} 3, \\
\text { FC5, T7, P7, O1, } \\
\text { O2, P8, T8, FC6, } \\
\text { F4, F8, AF4) }\end{array}$ & $\begin{array}{c}\text { Study } 1 \\
25 \text { medically stable, spinal } \\
\text { cord injury patients without } \\
\text { severe cognitive/ } \\
\text { psychiatric impairments } \\
\text { Cube rotation task - three } \\
\text { trials lasting } 8 \text { seconds each. } \\
\text { Study } 2 \\
\text { 21subjects with brain injury. } \\
\text { Virtual reality environment } \\
\text { with BCI - } 8 \text { training } \\
\text { sessions. }\end{array}$ & $\begin{array}{c}\text { Cognitive } \\
\text { flexibility, } \\
\text { working } \\
\text { memory, } \\
\text { complex } \\
\text { attentional } \\
\text { processes, } \\
\text { cognitive \& } \\
\text { motor } \\
\text { inhibition \& } \\
\text { processing } \\
\text { speed. }\end{array}$ & $\begin{array}{c}\text { 1.MATLAB scoring } \\
\text { program } \\
\text { 2. The Automated } \\
\text { Neuropsychological } \\
\text { Assessment Metrics } \\
\text { Stroop \& Go-No-Go } \\
\text { computerized tests, } \\
\text { Woodcock-Johnson } \\
\text { 3rd Edition Pair } \\
\text { Cancellation subtest, } \\
\text { \&Delis-Kaplan } \\
\text { Executive Functions } \\
\text { System Colour-Word } \\
\text { Interference test. }\end{array}$ & $\begin{array}{c}\text { Excessive reliance } \\
\text { on technology \& } \\
\text { financial feasibility. }\end{array}$ \\
\hline $\begin{array}{l}\text { Kotov et al. } \\
\text { (2019) }\end{array}$ & EEG Signals & $\begin{array}{l}44 \text { patients of } \\
2 \text { groups-- The main gp. }(22) \\
\text { given a program of complex } \\
\text { multimodal stimulation, } \\
\text { using BCI technology. The } \\
\text { comparison group (22) had } \\
\text { only training with the use of } \\
\text { BCI. }\end{array}$ & $\begin{array}{l}\text { Memory, } \\
\text { attention, } \\
\text { visual and } \\
\text { constructive } \\
\text { skills. }\end{array}$ & & \\
\hline $\begin{array}{l}\text { Laiz et al. } \\
\text { (2018) }\end{array}$ & $\begin{array}{l}\text { 16-channel } \\
\text { biomedical signal } \\
\text { amplifier with } \\
\text { g.tec USB } \\
\text { connection } \\
\text { (Austria) }\end{array}$ & $\begin{array}{c}32 \text { subjects } 22 \text { in the first } \\
\text { group of } 61-69 \text { years, and } 10 \\
\text { in the second group of } 70-81 \\
\text { years. } \\
5 \text { neurofeedback training } \\
\text { sessions alternated with } 5 \\
\text { work memory training } \\
\text { sessions for } 5 \text { weeks, }\end{array}$ & $\begin{array}{l}\text { Visuo-spatial, } \\
\text { spoken } \\
\text { language, } \\
\text { memory, } \\
\text { intellectual } \\
\text { processes \& } \\
\text { attention. }\end{array}$ & $\begin{array}{c}\text { Luria DNA } \\
\text { neuropsychological } \\
\text { battery. }\end{array}$ & $\begin{array}{l}\text { The sample size is } \\
\text { small. Further } \\
\text { recommendation of } \\
\text { this study would be } \\
\text { inclusion of a } \\
\text { control group }\end{array}$ \\
\hline $\begin{array}{l}\text { Martin et al. } \\
\text { (2018) }\end{array}$ & $\begin{array}{l}\mathrm{P} 300 \text { control } \\
\text { matrix }\end{array}$ & $\begin{array}{l}5 \text { participants ( } 4 \mathrm{M} \& 1 \mathrm{~F}) \\
\text { with traumatic brain } \\
\text { injury(TBI) as end users \& } 5 \\
\text { participants without TBI as } \\
\text { control group } \\
(1 \mathrm{M} \& 4 \mathrm{~F})\end{array}$ & $\begin{array}{l}\text { Memory, } \\
\text { semantic and } \\
\text { reasoning } \\
\text { skills, } \\
\text { language, and } \\
\text { learning, } \\
\text { attention\& } \\
\text { concentration. }\end{array}$ & Evaluation questions & $\begin{array}{l}\text { The small sample } \\
\text { size. } \\
\text { Since based on } \\
\text { prototype } \\
\text { development, the } \\
\text { study lacks evidence } \\
\text { on effectiveness. }\end{array}$ \\
\hline
\end{tabular}

\subsection{BCI in Brain Injury \& Spinal Cord Injury}

Two original studies were made to show how virtual reality and BCI may be integrated into neurorehabilitation (Salisbury et al., 2016). The first study investigated the feasibility of BCI with inpatient spinal cord injury. For this, 25 medically stable patients with sustained cervical-level (48\%) or thoracic-level (44\%) SCIs and residual tetraplegia (52\%), without severe cognitive or psychiatric impairment took part in the first study. The second study was conducted to explore the effect of two virtual environments on subjects with central nervous system insult. The participants were subjects with acquired traumatic brain injury, stroke, brain neoplasm, and anoxic injury. These studies gave a positive outcome regarding advanced technologies in the subacute stage of neurorehabilitation, concerning cognitive functions. The patients found the technology user-friendly and there was a remarkable improvement in their performance in the course of the sessions.

An attempt was made to design and validate a BCI for cognitive rehabilitation in brain-injured subjects based on a user-centered approach (Martin et al., 2018). The subjects with limited functional abilities were made to control computers through their brain waves with the help of the BCI. A research was conducted among community dwellers recovering from brain injury, with a group of therapists who worked together towards the rehabilitation of cognitive functions. The participants performed two tasks namely Find-a-Category and a Memory Card task. A home interface presented the therapy activities. This work was achieved by a group of academics, business partners, and service users. 


\begin{tabular}{|c|c|c|c|c|c|}
\hline Study & $\begin{array}{l}\text { Paradigm/ } \\
\text { Signals }\end{array}$ & Sample \& Method & $\begin{array}{c}\text { Tested } \\
\text { Variables }\end{array}$ & Outcome Measure & Limitations \\
\hline $\begin{array}{l}\text { Lee et al. } \\
\text { (2013) }\end{array}$ & $\begin{array}{l}\text { Frontal EEG } \\
\text { Fp1 \& Fp2 }\end{array}$ & $\begin{array}{c}31 \text { healthy elderly 60- } \\
\text { 70yrs. Intervention } \\
\text { gp.(15) } \\
\text { Control gp. (16). } \\
\text { Card-pairing memory } \\
\text { game with BCI, } 24 \\
\text { sessions each } 30 \\
\text { mins.over } 8 \text { weeks; } \\
\text { control gp. Week } 9 \text { to } 16\end{array}$ & $\begin{array}{c}\text { Immediate \& } \\
\text { delayed } \\
\text { memory, } \\
\text { language, } \\
\text { attention, } \\
\text { visuospatial/ } \\
\text { construction. }\end{array}$ & $\begin{array}{c}\text { Usability \& } \\
\text { acceptability } \\
\text { questionnaire } \\
\text { Repeatable Battery } \\
\text { for the Assessment } \\
\text { of } \\
\text { Neuropsychological } \\
\text { Status } \\
\text { (RBANS) scores. }\end{array}$ & $\begin{array}{l}\text { Covers only a small } \\
\text { subset of English } \\
\text { literate elderly. } \\
\text { Concerns about } \\
\text { RBANS. } \\
\text { Failure to avoid } \\
\text { placebo effect. }\end{array}$ \\
\hline $\begin{array}{l}\text { Lee et al. } \\
\text { (2015) }\end{array}$ & $\begin{array}{l}\text { Frontal EEG } \\
\text { Fp1 \& Fp2 }\end{array}$ & $\begin{array}{l}39 \text { Elderly of Chinese } \\
\text { ethnicity 60-70yrs. } \\
21 \text { subjects in } \\
\text { Intervention gp\& } 18 \text { in } \\
\text { control gp } \\
24 \text { half-hour sessions of } \\
\text { BCI/ } 8 \text { weeks. }\end{array}$ & $\begin{array}{c}\text { Immediate \& } \\
\text { delayed } \\
\text { memory, } \\
\text { language, } \\
\text { attention, } \\
\text { visuospatial/ } \\
\text { construction. }\end{array}$ & $\begin{array}{c}\text { Usability \& } \\
\text { acceptability } \\
\text { questionnaire } \\
\text { RBANS scores. }\end{array}$ & $\begin{array}{c}\text { Translated RBANS } \\
\text { forms not } \\
\text { validated. }\end{array}$ \\
\hline $\begin{array}{l}\text { Gomez-Pilar } \\
\text { et al. (2016) }\end{array}$ & $\begin{array}{c}\text { Event-related } \\
\text { desynchronization } \\
\text { (ERD) and event } \\
\text { related } \\
\text { synchronization } \\
\text { (ERS) of alpha } \\
\text { and beta } \\
\text { frequency bands. }\end{array}$ & $\begin{array}{l}63 \text { subjects (older than } \\
60 \text { years) with } 31 \\
\text { subjects }(13 \mathrm{M} \& 18 \mathrm{~F}) \text { in } \\
\text { neurofeedback (NFT) } \\
\text { group \& 32(9M\&23F) in } \\
\text { control group. NFT tasks } \\
\text { during } 5 \text { sessions- } \\
\text { imagine to lead the } \\
\text { cursor to the correct } \\
\text { target. } \\
\text { With progression of } \\
\text { difficulty level }\end{array}$ & $\begin{array}{l}\text { Visuospatial } \\
\text { skills, } \\
\text { linguistic } \\
\text { skills, } \\
\text { memory, } \\
\text { intellectual } \\
\text { functions and } \\
\text { attention. }\end{array}$ & $\begin{array}{c}\text { Luria adult } \\
\text { neuropsychological } \\
\text { diagnosis }\end{array}$ & $\begin{array}{l}\text { It is desirable to } \\
\text { extend the } \\
\text { population under } \\
\text { study for statistical } \\
\text { reasons. } \\
\text { Failure to make a } \\
\text { follow-up of the } \\
\text { cognitive } \\
\text { improvement }\end{array}$ \\
\hline $\begin{array}{l}\text { Yeo et al. } \\
\text { (2018) }\end{array}$ & EEG Signals & $\begin{array}{c}\text { Participants } 60-80 \text { yrs., } \\
\text { with no neuro psychiatric } \\
\text { diagnosis. } \\
24 \text { sessions in eight } \\
\text { weeks and booster } \\
\text { sessions for } 3 \text { months. } \\
\text { BRAINMEM with game } \\
\text { components }\end{array}$ & $\begin{array}{l}\text { Attention, } \\
\text { working } \\
\text { memory } \\
\text { \&delayed } \\
\text { recall. }\end{array}$ & $\begin{array}{c}\text { Repeatable Battery } \\
\text { for the Assessment } \\
\text { of Neuro } \\
\text { psychological } \\
\text { Status (RBANS). }\end{array}$ & $\begin{array}{l}\text { The sex moderation } \\
\text { effect not studied }\end{array}$ \\
\hline
\end{tabular}

\subsection{BCI in Dementia (mild)}

Dementia is a disease that evolves in the elderly, with varying degrees, affecting the daily life of the people suffering from it. A group of researchers attempted to assess whether cognitive training through a BCI will be effective in such subjects (Laiz et al., 2018). Total 32 subjects took part in the study, among these 22 were in the first group of 61-69 years, and 10 were in the second group of
70-81 years. The Luria-DNA neuropsychological battery was used to evaluate the subjects before and after training. The cognitive areas evaluated were visuospatial and linguistic skills, memory, intellectual functions, and attention. After training, compared to the second group, the first group showed significant improvement in all these aspects. The conclusion is that a suitable cognitive programme with BCI may delay cognitive impairment. 
Table 5 BCI on Healthy Adults

\begin{tabular}{|c|c|c|c|c|c|}
\hline Study & Paradigm/Signals & Sample \& Method & Tested Variables & Outcome Measure & Limitations \\
\hline $\begin{array}{l}\text { Rohani \& } \\
\text { Puthusser } \\
\text { ypady } \\
(2015)\end{array}$ & $\begin{array}{l}\text { Unipolar reference electrode } \\
\text { at the left earlobe, a ground } \\
\text { electrode at Fpz, an EOG } \\
\text { electrode below left eye, \& a } \\
\text { measurement electrode at Pz. }\end{array}$ & $\begin{array}{l}6 \text { healthy young subjects }(5 \mathrm{~m} \& \\
\text { 1f) aged } 24-32 . \quad 2 \text { oddball } \\
\text { attention experiments ANISPELL } \\
\& \text { T-SEARCH inside the VR } \\
\text { classroom. } 5 \text { trials each. }\end{array}$ & $\begin{array}{lll}\text { Sustained } & \text { visual } \\
\text { attention and } & \text { visual } \\
\text { discrimination } & \end{array}$ & $\begin{array}{l}\text { Non-linear Support } \\
\text { Vector Machine } \\
\text { (SVM) } \\
\text { Classifier to detect } \\
\text { the P300 potential }\end{array}$ & $\begin{array}{l}\text { P300 is likely to } \\
\text { change over time } \\
\text { due to task } \\
\text { adaptation. }\end{array}$ \\
\hline $\begin{array}{l}\text { Aliakbary } \\
\text { hosseinab } \\
\text { adi et al. } \\
(2017)\end{array}$ & $\begin{array}{l}\text { Monopolar EEG signals from } \\
18 \text { channels AF3, AFz, AF4, } \\
\text { F3, F1, Fz, F2, F4, 27 FC3, } \\
\text { FC1, FCz, FC2, FC4, C3, C1, } \\
\text { Cz, C2, C4 }\end{array}$ & $\begin{array}{l}12 \text { healthy participants }(6 \mathrm{M} \& \\
6 \mathrm{~F}) \text {, mean age } 24.25 \text {. Two tasks - } \\
\text { The control with normal attention } \\
\text { demand and the complex } \\
\text { secondary task with diversion } \\
\text { attention level }\end{array}$ & $\begin{array}{lr}\text { attention } & \text { variations } \\
\text { during } & \text { movement } \\
\text { execution } & \\
\end{array}$ & $\begin{array}{l}\text { MATLAB to extract } \\
\text { the time domain } \\
\text { feature \& EEGLAB } \\
\text { to extract the time } \\
\text { frequency features }\end{array}$ & $\begin{array}{l}\text { The combination } \\
\text { of movement and } \\
\text { attention made it } \\
\text { impossible to } \\
\text { ignore the } \\
\text { influence of dual } \\
\text { tasking. }\end{array}$ \\
\hline $\begin{array}{l}\text { Pei et al. } \\
(2018)\end{array}$ & $\begin{array}{l}\text { Alpha power density, theta \& } \\
\text { beta }\end{array}$ & $\begin{array}{l}20 \text { healthy volunteer subjects with } \\
\text { normal vision, } 2 \text { groups } \\
\text { neurofeedback (NF) group }(10)- \\
\text { alpha frequency neurofeedback } \\
\text { Sham NF gp. (10) - random } 4 \mathrm{~Hz} \\
\text { neurofeedback } 5 \text { sessions on } \\
\text { different days for } 5-7 \text { days. } \\
\text { Resting EEG recorded before \& } \\
\text { after each session }\end{array}$ & $\begin{array}{lr}\text { Episodic } & \text { memory, } \\
\text { working } & \text { memory \& } \\
\text { attention } & \text { network } \\
\text { processes. } & \end{array}$ & $\begin{array}{l}\text { Word pair task, } \\
\text { attention network test } \\
\& \text { backward digit } \\
\text { span task. }\end{array}$ & $\begin{array}{l}\text { Lack of auditory } \\
\text { feedback is a } \\
\text { limitation. }\end{array}$ \\
\hline $\begin{array}{l}\text { Firat et al. } \\
(2018)\end{array}$ & EEG Signals & $\begin{array}{l}\text { Seventy healthy participants. } \\
\text { Six tasks using a Brain-Computer } \\
\text { Interface system }\end{array}$ & $\begin{array}{l}\text { Cognitive state cluster } \\
\text { and task performance. } \\
\text { Pupil dilation, blink } \\
\text { rate, and Galvanic Skin } \\
\text { Response (GSR) data. }\end{array}$ & $\begin{array}{lr}\text { Nasa-Task } & \text { Load } \\
\text { Index, } & \text { Logistic } \\
\text { Regression, Decision } \\
\text { Tree, and } & \text { Neural } \\
\text { Networks } & \\
\end{array}$ & \\
\hline $\begin{array}{l}\text { Arvaneh } \\
\text { et al. } \\
(2019)\end{array}$ & P 300 based speller BCI & $\begin{array}{l}28 \text { healthy young adult } \\
\text { participants, (12 M\& 16 F) aged } \\
20 \text { to } 39 \text { yrs. Randomly assigned } \\
\text { to exp gp. (14) \& control gp. (14). } \\
\text { One session for } 1 \text { hour \& } 45 \text { mins. } \\
\text { P300-based speller task. } \\
\text { Questionnaire at the start\& end of } \\
\text { the session. }\end{array}$ & $\begin{array}{l}\text { Changes in EEG during } \\
\text { and pre-post training. } \\
\text { Changes in cognitive } \\
\text { performance }\end{array}$ & $\begin{array}{l}\text { Response time of } \\
\text { spatial attention task. }\end{array}$ & $\begin{array}{l}\text { Long-term } \\
\text { effects not } \\
\text { investigated. } \\
\text { Not applied to } \\
\text { those at the risk } \\
\text { of attention } \\
\text { problems like the } \\
\text { elderly. }\end{array}$ \\
\hline $\begin{array}{l}\text { Chuanqi et } \\
\text { al. (2019) }\end{array}$ & EEG optical flow & $\begin{array}{l}10 \text { subjects listening to and } \\
\text { imagining } 12 \text { well-known short } \\
\text { musical pieces }\end{array}$ & \begin{tabular}{lr}
\multicolumn{2}{c}{ Classification accuracy } \\
on the Open Music \\
$\begin{array}{l}\text { Imagery } \\
\text { Retrieval } \\
\text { dataset }\end{array}$ \\
\end{tabular} & $\begin{array}{l}\text { Open Music Imagery } \\
\text { Information Retrieval } \\
\text { Open MIIR dataset }\end{array}$ & \\
\hline $\begin{array}{l}\text { Karran et } \\
\text { al. (2019) }\end{array}$ & 32 electrode EEG montage & $\begin{array}{l}30 \text { healthy female participants } \\
\text { from Business School age 18-43. } \\
\text { Participants split into } 3 \text { groups: } \\
\text { no countermeasures (NCM), } \\
\text { continuous countermeasures } \\
(\mathrm{CCM}) \& \text { event-synchronized, } \\
\text { level-dependent countermeasures } \\
\text { (ECM). } 15 \text { min calibration task } \\
\& 90 \text { min business logistics task }\end{array}$ & $\begin{array}{l}\text { Mental demand, } \\
\text { physical demand, } \\
\text { temporal demand, } \\
\text { taskperformance, } \\
\text { frustration level \& } \\
\text { effort. }\end{array}$ & $\begin{array}{l}\text { Short version of the } \\
\text { NASA-Task Load } \\
\text { Index, the RAW- } \\
\text { Task Load Index. }\end{array}$ & $\begin{array}{l}\text { Functional near- } \\
\text { infrared } \\
\text { spectroscopy } \\
\text { (fNIRS) did not } \\
\text { prove a useful } \\
\text { tool with high } \\
\text { levels } \\
\text { discomfort_- of } \\
\text { problematic for } \\
\text { ecologically } \\
\text { valid tasks in } \\
\text { real-world } \\
\text { scenarios. }\end{array}$ \\
\hline $\begin{array}{l}\text { Gaume et } \\
\text { al. (2019) }\end{array}$ & $\begin{array}{l}\text { Electro des on frontal, } \\
\text { parietal and occipital regions } \\
\text { - Fp1, Fp2, F7, F3, F4, F8, } \\
\text { C3, C4, CP5, CP1, CP2, CP6, } \\
\text { P3, P4, O1 \& O2. }\end{array}$ & $\begin{array}{l}14 \text { healthy subjects }(11 \mathrm{~m} \& 3 \mathrm{f}) \\
\text { age 19-32. Motor control of a } \\
\text { cursor using a joystick. }\end{array}$ & $\begin{array}{l}\text { Mental, physical, } \\
\text { temporal demand, } \\
\text { performance, effort \& } \\
\text { frustration }\end{array}$ & $\begin{array}{l}\text { NASA Task Load } \\
\text { Index }\end{array}$ & $\begin{array}{l}\text { Insufficient to } \\
\text { prevent } \\
\text { modelling } \\
\text { confounders of } \\
\text { attentional load. }\end{array}$ \\
\hline
\end{tabular}




\subsection{BCI on Attention in Healthy Elderly}

Cognitive decline in aging is a prevailing issue which calls for interventions for improvement in attention. Some studies have taken up this demand and applied BCI based interventions in the elderly. An experiment was carried out with an EEG based BCI training programme which combined the positive effects of traditional computerized training interventions with neurofeedback training (NFT) (Lee et al.,2013). An eight-week training made up of 24 sessions of half an hour each was given. A questionnaire on the users' experience and feedback was administered at the end. After every session, the subjects had to report adverse events, if any. The Repeatable Battery for the Assessment of Neuropsychological Status (RBANS) recorded a change of total score pre- and post training. This was evidence for the efficacy of the system. Positive results were found from the questionnaire. The participants did not complain of any adverse events. The visuospatial/constructional attention showed significant improvement. This BCI based intervention system has the potentiality to improve memory and attention in healthy elderly. Senior users find it to be safe, handy and easy to use. However, another trial with participants having a mild cognitive impairment and early dementia is warranted.

The researchers repeated the study on a Chinese, healthy, elderly population. The research was conducted to find out whether cultural and linguistic factors affected cognitive training (Lee et al., 2015). They examined the efficacy of their BCI cognitive training programme in healthy Chinese-speaking Singaporean elderly. The same protocol as in the previous experiment was followed, and the control group received the same intervention after an 8-week waiting period. A questionnaire on the users' experience and feedback was given at the end.

For safety, after each session, users were questioned whether they experienced any discomfort. The users reported a total of 16 adverse events, but they were graded "mild". Only one was considered "moderate". The researchers have shown that cultural and linguistic factors did not influence BCI cognitive training.

A study was conducted to find out whether neurocognitive improvements and EEG changes can be brought about in the elderly through neurofeedback training with a motor imagerybased BCI (Gomez-Pilar et al., 2016). The neuropsychological test scores of both the experimental group and control group were compared and after five NFT sessions, the results showed significant improvements in the NFT group, in the four cognitive functions, visuospatial, oral language, memory, and attention. This experiment proved that NFT performed by a Motor Imagery-BCI enhanced cognitive functions.
A randomized controlled trial was carried out to examine the effectiveness of a personalized BCI system for cognitive training in the elderly (Yeo et al., 2018). The subjects were $60-80$ years old, without any neuropsychiatric issues. The subjects were divided into intervention and waitlist-control groups. The training system BRAINMEM was assigned to them. It has game components designed to improve attention, working memory, and delayed recall. 24 sessions were conducted over eight weeks followed by booster sessions once per month for three months. The Repeatable Battery for the Assessment of Neuropsychological Status (RBANS) was used to measure the outcome. The experimental group showed better performance than the waitlist group among men. Among the females, the between-group difference in improvement was not significant. The results of the study showed that a neurofeedback intervention is likely to be feasible in cognitive rehabilitation in the male elderly.

\subsection{BCI on Attention in Healthy Adults}

$\mathrm{BCI}$ can be a prospective instrument for training attention inside a VR classroom and this was investigated by some researchers (Rohani \& Puthusserypady, 2015). They created a training environment using a low-cost infra-red camera making up the illusion of 3D. Six healthy young subjects aged 24-32 participated in the experiment. On the scalp region above the parietal lobe of each participant, a single electrode was placed to elicit the P300 potential. This was found to be a successful demonstration of a non-intrusive, portable low-cost system targeting attention in an engaging environment. The study was conducted on healthy subjects, but it suggests a positive effect on ADHD subjects also.

An attempt was made, using 12 healthy adults of mean age 24, to classify EEG signals to identify attentional variations while carrying out motor tasks (Aliakbaryhosseinabadi et al., 2017). The motor task was a simple ankle dorsiflexion movement during which an auditory oddball task was applied to divert the users' attention. The researchers analysed every participant's attention levels and their effects on motor tasks. Motor cortex channels showed higher accuracy than other channels. The conclusion was that synchronous BCI systems with time-frequency feature may be employed to assess attention variation. The limitation is that the combination of movement and attention made it impossible to ignore the influence of dual tasking.

Some researchers made cognition assessments using an integrated neurofeedback system with dry electrodes (Pei et al., 2018). This integrated system combines BCI technology with a multithreading design and uses wearable, multichannel, dry electrode EEG acquisition equipment. For this, 20 healthy volunteers were divided into an NF (neurofeedback) group \& a sham NF group. They had five treatment sessions/week. Compared to the sham NF group, the NF group showed higher alpha frequency band power. Thus, the 
NF group performed better in working memory. This integrated system is expected to be an effective assessment system for neurofeedback training and cognitive function and may be used personally and clinically. This system may be updated and improved. According to some studies, a combined visual and auditory feedback modality achieved better BCI performance, enabling participants to focus attention on the task (Gargiulo et al., 2012; Fabien et al., 2013).

A classification of BCI users based on cognition was made (Firat Ozkan \& Kahya, 2018). The study was meant to examine cognitive state using BCI systems. Seventy healthy participants were selected to perform six tasks using a BCI system. After each task, the participants filled Nasa-TLX (task load index) forms so that their task performances could be measured. The K-means method was used to create cognitive state clusters from the data collected. From the obtained data, the participants were classified into low or high risk, based on their cognitive state. The processing of classified data was done to evaluate the consistency of this classification. A consistency between $87.1 \%$ and $100 \%$ with other techniques was observed.

The use of a BCI to modulate the level of sustained attention over a long duration business logistics task has been studied (Karran et al., 2019). Total, 30 healthy female participants from Business School aged between 18 and 43 were selected and allocated to groups of no countermeasures (NOCM), continuous countermeasures (CCM), and event synchronized, level-dependent countermeasures (ECM). The researchers worked under the hypothesis that self-regulating sustained attention through neurofeedback would have the following results: task engagement would become greater; error rate would be decreased, and task performance would be improved. The results proved that selfregulating sustained attention can keep the users engaged for a long time, and moderately enhance task performance while decreasing errors. A group of researchers introduced a cognitive $\mathrm{BCI}$ based continuous performance task to monitor variations in visual sustained attention (Gaume et al., 2019). For this, 14 healthy subjects, 11 males \& 3 females aged 19-32 were selected for the study. The task involved the use of a joystick to control a cursor. The continuous task enables keeping track of variations of visual sustained attention. Furthermore, the researchers have designed a task in which cognitive functions other than sustained attention are minimally involved. To update the visual information from our sensory inputs continuously, sustained attention is necessary. This was their focus rather than processing of the information stored in working memory.

A P300-based BCI for improving attention was devised by some researchers (Arvaneh et al., 2019). They modified the P300-based speller BCI into an engaging neurofeedback game. They designed the game in such a way that it adapted its difficulty level according to the user's performance, requiring the production of a stronger P300. The neurofeedback training was for only 30 minutes. From the obtained results it was found that the training brought about a remarkable improvement in the Event-Related Potentials (ERP) components of the target trials. A weakening of the corresponding ERP components was observed in the non-target trials. A spatial attention task after the neurofeedback training proved that the response time was significantly improved in the experimental group. From the study, it can be inferred that this neurofeedback training tool is bound to improve attention, specifically for subjects with attention disorders. However, the long term effects of this training remain to be investigated.

A new approach to improve the accuracy of EEG classification in BCI was taken up by some researchers (Chuanqi et al., 2019). They pay attention to the fact that the human brain has different functional areas for different human activities. They propose an attention-based transfer learning framework that includes a cross domain encoder and an attention-based decoder with a recurrent neural network (RNN). They applied this approach to a dataset called Open Music Imagery Information Retrieval (Open MIIR), involving 10 subjects listening to and imagining 12 well-known short musical pieces. They show that brain functional areas associated with new activities may be discovered by using attention mechanisms.

\section{Conclusion}

Attention is a fundamental mechanism of the brain, enabling the selection of relevant information and suppression of irrelevant signals. This review has given an overview of the studies in BCI on attention in different neurological disorders as well as healthy adults and elderly. BCI based neuro-feedback training is found to be effective in enhancing attention in ADHD subjects. Researches support that $\mathrm{BCI}$ based attention training programme for ADHD is relatively simple to use, convenient and accessible over most other cognitive training programmes utilizing EEG information, and they also suggest that it could be developed into home-based treatment. In ALS subjects, behavioural tasks like visual presentation and change detection, as well as a P300 speller task are effective in improving attention.

In ASD subjects, social cognition is found improved due to BCI intervention. In spinal cord injury patients, BCI integrated with virtual reality was experimented with as neurorehabilitation with a positive outcome. An evaluation after cognitive training through BCI on subjects suffering from early dementia showed that such a cognitive programme may delay cognitive impairment.BCI based neurofeedback training promises neurocognitive improvement and EEG changes in the elderly. Different cognitive assessments have been tried on healthy adults, like classifying EEG signals to identify attentional variations during a motor task, BCI based 
neurofeedback therapy with a multithreading design in cognitive assessment, BCI as a potential training tool for attention inside a virtual reality classroom, BCI based continuous performance task to monitor variations in visual sustained attention, and a P300based BCI. In post-stroke subjects, BCI combined with exoskeleton technology of a multimodal stimulation offered better therapeutic results. More than half of stroke survivors suffer from cognitive defects, which determine broader outcomes than physical disability. Cognitive productivity can be reduced by impaired attention, even when other cognitive functions are intact. Attention is also associated with balance, functional independence, and daily living. Hence attention training using BCI is undoubtedly a useful tool in post-stroke rehabilitation. From this review, it is evident that hardly any research has been done on using $\mathrm{BCI}$ for enhancing attention in post-stroke subjects. So there arises the necessity for making a study on the effects of BCI based attention training in post-stroke subjects, as attention is the key for learning motor skills that get impaired following a stroke. Currently, various researches have been under investigation to determine the effects of a BCI based training programme for the enhancement of attention in post-stroke subjects.

\section{Acknowledgments}

We place on record our indebtedness and sense of gratitude to Dr. Pamela Oliver $\mathrm{PhD}$, Retd. Professor \& HOD of English, SarahTucker College, for her expert guidance and valuable suggestions for this study.

\section{Conflicts of interest: None}

\section{References}

Aliakbaryhosseinabadi S, Kamavuako EN, Jiang N, Farina D, Mrachacz-Kersting N (2017) Classification of EEG signals to identify variations in attention during motor task execution. Neuroscience Methods 284: 27-34.

Amaral C, Mouga S, Simões M, Pereira HC, Bernardino I, Quental H, Playle R, McNamara R, Oliveira G, Castelo-Branco M (2018) A Feasibility Clinical Trial to Improve Social Attention in Autistic Spectrum Disorder (ASD) Using a Brain Computer Interface. Frontiers in Human Neuroscience 12: 477.

Arvaneh M, Robertson IH, Ward TE (2019) A P300-Based BrainComputer Interface for Improving Attention. Frontiers in Human Neuroscience 12: 524.

Ayaz H, Shewokis PA, bunce S, Izzetogly K, Willems B, Onaral $\mathrm{B}(2012)$ Optical brain monitoring for operator training and mental workload assessment. Neuro-Image 59: 36-47.

Beauregard M, Levesque J (2006) Functional magnetic resonance imaging investigation of the effects of neurofeedback training on the neural bases of selective attention and response inhibition in children with attention-deficit/hyperactivity disorder. Applied Psychophysiology and Biofeedback 31:.3-20.

Carelli L, Solca F, Faini A, Meriggi P, Sangalli D, Cipresso P, Riva G, et al. (2017) Brain computer interface for clinical purposes: cognitive assessment and rehabilitation. BioMed Research International 2017: 1695290.

Chuanqi T, Tao FS, Fang KB, Zhang W(2019) Attention-based Transfer Learning for Brain-Computer Interface. IEEE International Conference on Acoustics, Speech and Signal Processing (ICASSP), Brighton, United Kingdom, Pp. 1154-1158.

Daly JJ, Huggins JE (2015) Brain- Computer Interface: Current and Emerging Rehabilitation Applications. Archives of Physical Medicine and Rehabilitation 96(3 Suppl 1): S1-7.

Denis E, Small S, Solodkin A, Dettmers C, McNamara A, Binkofski F, Buccino G (2007) Action observation has a positive impact on rehabilitation of motor deficits after stroke. NeuroImage 36: T164-73.

Dokkum LEH van, Ward T, Laffont I (2015) Brain computer interfaces for neurorehabilitation - its current status as a rehabilitation strategy post-stroke. Annals of Physical and Rehabilitation Medicine 58: 3-8.

Enriquez-Geppert S, Smit D, Pimenta MG, Arns M(2019) Neurofeedback as a Treatment Intervention in ADHD: Current Evidence and Practice. Current Psychiatry Reports 21: 46.

Esghaei M, Daliri MR (2014) Decoding of visual attention from LFP signals of macaque MT. PLoS ONE 9(6):.1-10.

Fabien L, Florian L, Christian M (2013) Flaws in current human training protocols for spontaneous brain-computer interfaces: Lessons learned from instructional design. Frontiers in Human Neuroscience.7:568.

Gargiulo GD, Mohamed A, McEwan AL, Bifulco P, Cesarelli M, Jin CT, Ruffo M, Tapson J, van Schaik A (2012) Investigating the role of combined acoustic-visual feedback in one-dimensional synchronous brain computer interfaces, a preliminary study. Medical Devices 5: 81-88.

Gaume A, Dreyfus G, Vialatte FB (2019) A cognitive braincomputer interface monitoring sustained attentional variations during a continuous task. Cognitive Neurodynamics13: 257-269.

Gomez-Pilar J, Corralejo R, Nicolas-Alonso LF, Alvarez D, Horner R (2016) Neurofeedback training with a motor imagerybased BCI: neurocognitive improvements and EEG changes in the elderly. Medical \& Biological Engineering \& Computing 54: $1655-1666$. 
Hoffmann U, Vesin JM, Ebrahimi T, Diserens K(2008) An Treating Attention Deficit Hyperactivity Disorder. PLoS ONE efficient P300-based brain-computer interface for disabled 7(10): subjects. Journal of Neuroscience Methods 167: 115-125.

James W(1891) The Principles of Psychology. Macmillan,London, Pp.403.

Jensen PS, Hinshaw SP, Kraemer HC, Lenora N, Newcorn JH, Abikoff $\mathrm{HB}(2001)$ ADHD comorbidity findings from the MTA study: comparing comorbid subgroups. Journal of the American Academy of Child and Adolescent Psychiatry 40(2): 147-58.

Jiang L, Guan C, Zhang H, Wang C, Jiang B (2011) Brain computer interface-based 3D game for attention training and rehabilitation. Proceedings of the 6th IEEE Conference on Industrial Electronics and Applications, Beijing: 124-127.

Jiang Y, Abiri R, Zhao X (2017) Tuning Up the Old Brain with New Tricks: Attention Training via Neurofeedback. Frontiers in Aging Neuroscience 9: 52.

Karran AJ, Demazure T, Leger PM, Labonte-LeMoyne E, Senecal S, Fredette M, Babin G (2019) Toward a Hybrid Passive BCI for the Modulation of Sustained Attention Using EEG and fNIRS. Frontiers in Human Neuroscience 13: 393.

Kawatani J, Mizuno K, Shiraishi S, Takao M, Joudoi T, Fukuda S, Tomoda A (2011) Cognitive dysfunction and mental fatigue in childhood chronic fatigue syndrome - A 6-month follow-up study. Brain and Development 33(10): 832-841.

Kotov S, Elena I, Slyun'kova E (2019) Usage of Brain Computer Interface+exoskeleton Technology as a Part of Complex Multimodal Stimulation in the Rehabilitation of Patients With Stroke. Zhurnalnevrologiiipsikhiatriiimeni S.S. Korsakova 119: 37.

Laiz MN, Diaz Sagrario DV, Collado Natlia R, Gomez-Pilar J, Roberto H (2018) Potential benefits of a cognitive training program in mild cognitive impairment (MCI). Restorative Neurology and Neuroscience 36(2): 207-213.

Lee TS, Alexa Goh SJ, Quek SY, Phillips R, Guan C, Cheung YB, et al. (2013) A brain-computer interface based cognitive training system for healthy elderly: a randomized control pilot study for usability and preliminary efficacy. PloS ONE 8(11): e79419.

Lee TS, Quek SY, Alexa Goh SJ, Phillips R, Guan C, Cheung YB, et al. (2015) A pilot randomized controlled trial using EEG-based brain-computer interface training for a Chinese-speaking group of healthy elderly. Clinical Interventions in Aging10: 217-227.

Lim CG, Lee TS, Guan C, Sheng Fung DS, Zhao Y, et al. (2012) A Brain-Computer Interface Based Attention Training Program for

Lim CG, Poh XWW, Fung SSD, Guan C, Bautista D, Cheung YB, Zhang H, Yeo SN, Krishnan R, Lee TS (2019) A randomized controlled trial of a brain computer interface based attention training program for ADHD. PLoS ONE 10 (1371): e0216225.

Luaute J, Morlet D, Jeremie M(2015) BCI in patients with disorders of consciousness: Clinical perspectives. Annals of Physical and Rehabilitation Medicine58: 29-34.

Lutz A, Slagter HA, Rawlings NB, Francis AD, Greischar LL, Davidson RJ (2009) Mental training enhances attentional stability: Neural and behavioural evidence. Journal of Neuroscience 29(42): 13418-13427.

Mandrick K, Derosiere G, Dray G, Coulon D, Micalef JP, Perrey S (2013a) Prefrontal cortex activity during motor tasks with additional mental load requiring attentional demand: a nearinfrared spectroscopy study. Journal of Neuroscience Research 76: $156-62$.

Mandrick K, Derosiere G, Dray G, Coulon D, Micalef JP, Perrey S (2013b) Utilizing slope method as an alternative data analysis for functional near-infrared spectroscopy-derived cerebral hemodynamic responses. International Journal of Industrial Ergonomics 43: 335-41.

Martin S, Armstrong E, Thomson E, Vargiu E, Solà M, et al. (2018) A Qualitative Study Adopting a User-Centered Approach to Design and Validate a Brain Computer Interface for Cognitive Rehabilitation for People With Brain Injury. Assistive Technology 30(5): 233-241.

Mehdi OS, Lebedev MA, Sorensen HBD, Puthusserypady S(2016)Neurofeedback Therapy for Enhancing Visual Attention: State-of-the-Art and Challenges. Frontiers in Neuroscience 10: 352 .

Millán JDR, Rupp R, Müller-Putz GR, Murray-Smith R, Giugliemma C, Tangermann M, Vidaurre C, et al. (2010) Combining brain-computer interfaces and assistive technologies: state-of-the-art and challenges. Frontiers in Neuroscience 4: 161.

Mizuno K, Tanaka M, Fukuda S, Imai-Matsumura K, Watanabe Y (2011) Relationship between cognitive functions and prevalence of fatigue in elementary and junior high school students. Brain and Development 33(6): 470-479.

Muller-Putz G, Pokorny C, Klobassa D, Horki P (2013) A single switch BCI based on passive and imagined movements: towards restoring communication in minimally conscious patients. International Journal of Neural Systems 23:1250037.

Munoz JE, Lopez JF, Lopez DS, Lopez A (2015) Design and Creation of a BCI Videogame to Train Sustained Attention in 
Children with ADHD. Proceedings of the 10th Computing Colombian Conference, September 2015.

Naci L, Monti MM, Cruse D, Kübler A, Sorger B, Goebel R, et al. (2012) Brain-computer interfaces for communication with nonresponsive patients. Annals of Neurology 72:312-23.

Firat Ozkan N, Kahya E (2018) Classification of BCI Users Based on Cognition. Hindawi Computational Intelligence and Neuroscience. 2018: 6315187, 10 pages.

Pei G, Wu J, Chen D, Guo G, Liu S, Hong M, Yan T(2018) Effects of an Integrated Neurofeedback System with Dry Electrodes: EEG Acquisition and Cognition Assessment. Sensors 18: 3396.

Posner MI (1975) Psychobiology of attention, Handbook of Psychobiology, Eds MS Gazzaniga and C Blakemore, Academic Press, New York, NY, Pp. 441-480.

Qian X, Yi Loo BR, Castellanos FX, Liu S, Koh HL, et al. (2018) Brain-computer-interface-based intervention re-normalizes brain functional network topology in children with attention deficit/hyperactivity disorder. Translational Psychiatry 8: 149.

Ramos-Murguialday A, Broetz D, Rea M, Läer L, Yilmaz O, Brasil FL, Liberati G, Curado MR, Garcia-Cossio E, Vyziotis A, Cho W, et al. (2013) Brain machine interface in chronic stroke rehabilitation: a controlled study. Annals of Neurology 74: 100-8.

Riccio A, Schettini F, Simione L, Pizzimenti A, Inghilleri M, Olivetti-Belardinelli M, Mattia D, Cincotti F (2018) On the Relationship Between Attention Processing and P300-Based Brain Computer Interface Control in Amyotrophic Lateral Sclerosis. Frontiers in Human Neuroscience 12: 165.

Riccio A, Simione L, Schettini F, Pizzimenti A, Inghilleri M, Belardinelli MO, Mattia D, Cincotti F (2013)Attention and P300based BCI performance in people with amyotrophic lateral aclerosis. Frontiers in Human Neuroscience 7: 732.

Rohani DA, Puthusserypady S(2015) BCI inside a virtual reality classroom: a potential training tool for attention. EPJ Nonlinear Biomedical Physics 3: 12.

Salisbury DB, Dahdah M, Driver S, Parsons TD, Richter KM(2016) Virtual Reality and Brain Computer Interface in Neurorehabilitation. Baylor University Medical Center Proceedings 29(2): 124-127.
Sciberras E, Lycett K, Efron D, Mensah F, Gerner B, Hiscock H (2014) Anxiety in children with attention-deficit/hyperactivity disorder. Pediatrics. 133(5):801-8.

Sellers EW, Donchin E (2006)AP300-based brain-computer interface: initial tests by ALS patients. Clinical Neurophysiology117: 538-548.

Sellers EW, Vaughan TM, Wolpaw JR (2010) A brain-computer interface for long-term independent home use. Amyotrophic Lateral Sclerosis 11: 449-45.

Shapiro K, Schmitz F, Martens S, Hommel B, Schnitzler A (2006) Resource sharing in the attentional blink. Neuroreport 17(2):163166

Spence C, Driver J (1997) On measuring selective attention to an expected sensory modality. Perception and Psychophysics 59(3): $389-403$.

Spence C, Nicholls ME, Driver J (2001) The cost of expecting events in the wrong sensory modality. Perception and Psychophysics 63(2): 330-336.

Treder MS, Purwins H, Miklody D, Sturm I, Blankertz B (2014)

Decoding auditory attention to instruments in polyphonic music using singletrial EEG classification. Journal of Neural Engineering 11(2): 026009.

Van Doren J, Arns M, Heinrich H, Vollebregt MA, Strehl U, Loo SK (2018) Sustained effects of neurofeedback in ADHD: A systematic review and meta-analysis. European Child and Adolescent Psychiatry, Pp. 1- 13.

Xia W, Shen L, Zhang J (2015) Comorbid anxiety and depression in school-aged children with attention deficit hyperactivity disorder (ADHD) and self-reported symptoms of ADHD, anxiety, and depression among parents of school-aged children with and without ADHD. Shanghai Archives of Psychiatry 27(6):356-67.

Yeo SN, Lee TS, Sng WT, Heo MQ, Bautista D, Cheung YB, Zhang H, Wang C, Chin ZY, Feng L, Zhou J, Chong MS, Ng TP, Krishnan KR, Guan C (2018) Effectiveness of a Personalized Brain-Computer Interface System for Cognitive Training in Healthy Elderly: A Randomized Controlled Trial. Journal of Alzheimer's Disease 66 (1): 127-138. 